\title{
New 2,4,5-triarylimidazoles based on a phenylalanine core: synthesis, photophysical characterization and evaluation as fluorimetric chemosensors for ion recognition
}

\author{
Cátia I. C. Esteves, M. Manuela M. Raposo, Susana P. G. Costa* \\ Centre of Chemistry, University of Minho, Campus of Gualtar, 4710-057 Braga, Portugal
}

\begin{abstract}
Novel fluorescent 4,5-diarylimidazolyl-phenylalanines 3a-d were prepared by reaction of $\mathrm{N}$-tert-butyloxycarbonyl-4-formylphenylalanine methyl ester and appropriate (hetero)aromatic diones. The photophysical properties of these new unnatural amino acids were evaluated by UV-Vis absorption and fluorescence spectroscopy in solvents of different character and aqueous mixtures with acetonitrile. They were evaluated as novel amino acid based fluorimetric chemosensors for ions through spectrophotometric and spectrofluorimetric titrations with biologically and analytically important anions and cations such as $\mathrm{F}^{-}, \mathrm{OH}^{-}$, $\mathrm{Cu}^{2+}$ and $\mathrm{Fe}^{3+}$. The results indicate that there was a strong interaction through the donor $\mathrm{N}, \mathrm{O}$ and $\mathrm{S}$ atoms at the side chain, especially for 4,5-di(furan-2'-yl)imidazolyl-phenylalanine 3a and 4,5-di(thiophen-2'-yl)imidazolyl-phenylalanine $\mathbf{3 b}$ with $\mathrm{Cu}^{2+}$ and $\mathrm{Fe}^{3+}$, in a 1:1 complex stoichiometry. The photophysical and metal ion sensing properties of these amino acids suggest that they can be suitable for incorporation into chemosensory peptidic frameworks.
\end{abstract}

\section{Introduction}

Optical sensing based on colorimetric and fluorimetric probes is a very appealing topic of research, considering the large number of chromo/fluorophores available and the simple instrumentation required (when using colorimetric probes), and the low detection limits (when using fluorescence probes) [1]. Hence, the design of novel organic fluorophores that can be used in biomolecule labelling and chemosensing of organic and inorganic molecules involved in biological pathways is worth exploring [2]. The development of probes containing binding sites capable of sensing anions and cations, preferably in aqueous media, is a very active area within the chemical sensing field [3]. Imidazole derivatives are known as neutral binding groups for anions [4], and the coordination ability of the imidazole group depends on the acidity of the NH proton that can be modulated by suitable substituents such 
as heteroaromatic rings like thiophene, pyrrole or furan. On the other hand, the two nitrogen atoms in imidazole enable the coordination of metal cations by this five-membered heterocycle [5]. 2,4,5-Triarylimidazoles have found application in materials sciences for their interesting optoelectronic properties that can be tuned by careful selection of substituents at positions 2, 4 and 5: replacement of the aryl group by an heterocyclic group results in larger $\pi$-conjugated systems with improved optical properties for application in two-photon absorption applications, two-photon fluorescence microscopy, high density storage and 3D microfabrication, nonlinear optics, OLEDs, and chemosensors [6]. 2,4,5-Triarylimidazoles have also been applied in medicinal chemistry, for example as ligands for $\mathrm{Ru}(\mathrm{II})$ and $\mathrm{Pt}(\mathrm{II})$ complexes, as probes of DNA structure or new therapeutic agents due to their capacity to bind or interact with DNA [7].

Synthetically modified amino acids are useful for the preparation of intrinsically labelled peptides with tailored properties such as increased fluorescence, conformational rigidity, and metal complexation ability, among others. Recent examples in the literature refer the use of fluorescent unnatural amino acids in studies of molecular flexibility and protein folding, substrate binding activity of proteins, antigenicity or enzymatic activity, targeting peptides for molecular imaging, peptidomimetics biological activity and protein engineering [8]. Metallic cations can be complexed through $\mathrm{N}, \mathrm{O}$ and $\mathrm{S}$ donor atoms in amino acids, at the main and side chains, and in aromatic heterocycles, whereas anion coordination, based on hydrogen bonding and electrostatic interactions, can arise from amino acid side and main chain $\mathrm{OH}$ and $\mathrm{NH}$ groups, or from $\mathrm{NH}$ groups in heterocycles [9]. Therefore, the insertion of suitable heterocyclic systems at the side chain of natural amino acids can add extra functionality to the resulting amino acid, bearing a metal ion chelating site for stable complex formation and subsequent incorporation into a peptide.

Given these facts, our current research interests include the synthesis and characterization of unnatural amino acids bearing fluorescent oxygen, nitrogen and sulphur heterocycles [10], imidazole and benz-X-azole derivatives with interesting optical properties [11] and innovative heterocyclic colorimetric/fluorimetric chemosensors for anions and cations based on amino acid moieties [12]. To the best of our knowledge, this is the first report on the synthesis of 2,4,5-triaryl-imidazole derivatives combined with an amino acid core, the evaluation of the photophysical properties in different solvents and the chemosensing ability in the presence of anions and cations. 


\section{Experimental}

\subsection{Synthesis general}

All melting points were measured on a Stuart SMP3 melting point apparatus. TLC analyses were carried out on $0.25 \mathrm{~mm}$ thick precoated silica plates (Merck Fertigplatten Kieselgel $60 \mathrm{~F}_{254}$ ) and spots were visualised under UV light. Chromatography on silica gel was carried out on Merck Kieselgel (230-240 mesh). IR spectra were determined on a BOMEM MB 104 spectrophotometer using $\mathrm{KBr}$ discs. NMR spectra were obtained on a Bruker Avance III 400 at an operating frequency of $400 \mathrm{MHz}$ for ${ }^{1} \mathrm{H}$ and $100.6 \mathrm{MHz}$ for ${ }^{13} \mathrm{C}$ using the solvent peak as internal reference at $25^{\circ} \mathrm{C}$. All chemical shifts are given in ppm using $\delta_{\mathrm{H}} \mathrm{Me}_{4} \mathrm{Si}=0 \mathrm{ppm}$ as reference. Assignments were supported by spin decoupling-double resonance and bidimensional heteronuclear correlation techniques. Low and high resolution mass spectra were obtained at "C.A.C.T.I. Unidad de Espectrometria de Masas" at the University of Vigo, Spain. Commercially available reagents 2a-d were purchased from Sigma-Aldrich, ACROS, or TCI and used as received. Compound $\mathbf{1}$ was synthesised as reported elsewhere [13].

\subsection{General procedure for the synthesis of imidazolyl-phenylalanines 3a-d}

$N$-tert-Butyloxycarbonyl-4-formylphenylalanine methyl ester 1 (1 equiv) and the appropriate dione 2 ( 1 equiv) were dissolved in acetic acid $(5 \mathrm{~mL} / \mathrm{mmol})$ in the presence of ammonium acetate (20 equiv) and heated at reflux for 2 hours. After cooling, the mixture was poured over crushed ice and extracted with ethyl acetate $(3 \times 5 \mathrm{~mL})$. After drying the organic layer over anhydrous $\mathrm{MgSO}_{4}$, the solvent was removed in a rotary evaporator and a solid was obtained. The crude solid was purified by column chromatography, using mixtures of dichloromethane and methanol of increasing polarity as eluent.

\subsection{1. $N$-acetyl-4-(4',5'-di(furan-2''-yl)imidazol-2'-yl) phenylalanine methyl ester (3a).}

Starting from aldehyde $1\left(0.050 \mathrm{~g}, 0.163 \times 10^{-3} \mathrm{~mol}\right)$ and 1,2-di(furan-2-yl)ethane-1,2-dione 2a $\left(0.031 \mathrm{~g}, 0.163 \times 10^{-3} \mathrm{~mol}\right)$, compound 3a was isolated as an orange solid $(0.035 \mathrm{~g}, 0.084$ $\left.\times 10^{-3} \mathrm{~mol}, 42 \%\right) . \mathrm{mp}=209.8-210.7^{\circ} \mathrm{C} . \mathrm{IR}\left(\mathrm{KBr} 1 \%, \mathrm{~cm}^{-1}\right): v=3340,3078,2928,1737$, 1691, 1633, 1596, 1526, 1518, 1437, 1389, 1368, 1322, 1291, 1256, 1220, 1166, 1109, 1086, 1059, 1029, 994, 971, 920, 854, 813, 796, 772, 684. ${ }^{1} \mathrm{H}$ NMR (400 MHz, $\left.\mathrm{CDCl}_{3}\right): \delta=1.99$ (s, 3H, $\left.\mathrm{CH}_{3} \mathrm{Ac}\right), 3.06-3.20\left(\mathrm{~m}, 2 \mathrm{H}, \beta-\mathrm{CH}_{2}\right), 3.72\left(\mathrm{~s}, 3 \mathrm{H}, \mathrm{OCH}_{3}\right), 4.85-4.88(\mathrm{~m}, 1 \mathrm{H}, \alpha-\mathrm{H})$, 
6.11 (d, J 7.6 Hz, 1H, NH Ac), 6.53 (dd, J 3.6 and 1.8 Hz, 2H, $2 \times$ H4' '), 6.99 (d, J $3.6 \mathrm{~Hz}$, 2H, $2 \times \mathrm{H} 3$ ' '), $7.14(\mathrm{~d}, J 8.0 \mathrm{~Hz}, 2 \mathrm{H}, \mathrm{H} 2$ and H6), 7.50 (d, J $1.8 \mathrm{~Hz}, 2 \mathrm{H}, 2 \times \mathrm{H} 5$ ' '), 7.84 (d, J $8.0 \mathrm{~Hz}, 2 \mathrm{H}, \mathrm{H} 3$ and H5). ${ }^{13} \mathrm{C} \mathrm{NMR}\left(100.6 \mathrm{MHz}, \mathrm{CDCl}_{3}\right): \delta=23.07\left(\mathrm{CH}_{3} \mathrm{Ac}\right), 37.72\left(\beta-\mathrm{CH}_{2}\right)$, $52.43\left(\mathrm{OCH}_{3}\right), 53.16(\alpha-\mathrm{C}), 107.80\left(\mathrm{C} 3{ }^{\prime \prime}\right), 111.76(\mathrm{C} 4$ ') $), 125.81$ (C3 and C5), 127.24 (C4' or C5'), 127.87 (C4'or C5'), 129.69 (C2 and C6), 130.28 (C4), 137.20 (C1), 141.54 (C5',), 145.83 (C2') 155.33 (C2’'), 169.89 (C=O Ac), 171.90 (C=O ester). UV/Vis (ethanol, nm): $\lambda_{\max }(\log \varepsilon)=317$ (4.21). MS $m / z(E S I, \%): 420\left([\mathrm{M}+\mathrm{H}]^{+}, 100\right)$. HRMS: $m / z$ (ESI) calcd for $\mathrm{C}_{23} \mathrm{H}_{22} \mathrm{~N}_{3} \mathrm{O}_{5}$ 420.15606; found 420.15508 .

\subsection{2. $N$-acetyl-4-(4',5'-di(thiophen-2''-yl)imidazol-2'-yl) phenylalanine methyl ester}

(3b). Starting from aldehyde $1\left(0.050 \mathrm{~g}, 0.162 \times 10^{-3} \mathrm{~mol}\right)$ and 1,2-di(thiophen-2-yl)ethane1,2-dione $2 \mathbf{b}\left(0.036 \mathrm{~g}, 0.162 \times 10^{-3} \mathrm{~mol}\right)$, compound $\mathbf{3 b}$ was isolated as a yellow solid $(0.038$ $\left.\mathrm{g}, 0.084 \times 10^{-3} \mathrm{~mol}, 45 \%\right) . \mathrm{mp}=215.9-217.0{ }^{\circ} \mathrm{C} . \mathrm{IR}\left(\operatorname{KBr} 1 \%, \mathrm{~cm}^{-1}\right): \mathrm{v}=3431,3146,2977$, $1711,1655,1596,1534,1513,1446,1419,1391,1366,1332$, 1259, 1195, 1168, 1120, 1060, 1020, 994, 959, 939, 912, 892, 871, 817, 735, 695, 646, 613. ${ }^{1} \mathrm{H}$ NMR (400 MHz, DMSO$\left.d_{6}\right): \delta=1.79\left(\mathrm{~s}, 3 \mathrm{H}, \mathrm{CH}_{3} \mathrm{Ac}\right), 2.88-3.07\left(\mathrm{~m}, 2 \mathrm{H}, \beta-\mathrm{CH}_{2}\right), 3.59\left(\mathrm{~s}, 3 \mathrm{H}, \mathrm{OCH}_{3}\right), 4.47-4.52(\mathrm{~m}$, 1H, $\alpha-\mathrm{H}$ ), 7.00 (dd, $J 5.2$ and $3.6 \mathrm{~Hz}, 1 \mathrm{H}, \mathrm{H} 4$ ' '), 7.15 (dd, J 3.6 and 0.8 Hz, 1H, H3'”), 7.20 (dd, J 4.2 and 3.6 Hz, 2H, H4' ' '), 7.31 (d, J 8.4 Hz, 2H, H2 and H6), 7.40-7.42 (m, 2H, H5', and H3', '), 7.69 (d, J 5.2 and 1.2 Hz, 1H, H5','), 7.93 (d, J 8.4 Hz, 2H, H3 and H5), 8.36 (d, $J 8.0 \mathrm{~Hz}, 1 \mathrm{H}, \mathrm{NH} \mathrm{Ac}), 12.80$ (br s, $1 \mathrm{H}, \mathrm{NH}) .{ }^{13} \mathrm{C}$ NMR (100.6 MHz, DMSO-d 6 ): $\delta=22.23$ $\left(\mathrm{CH}_{3} \mathrm{Ac}\right), 36.57\left(\beta-\mathrm{CH}_{2}\right), 51.84\left(\mathrm{OCH}_{3}\right), 53.43(\alpha-\mathrm{C}), 120.60\left(\mathrm{C}^{\prime}\right.$ ' or $\mathrm{C} 5$ '), $123.39\left(\mathrm{C} 3{ }^{\prime \prime}\right)$, 124.84 (C3'”), 125.23 (C3 and C5), 127.31 (C4'), 127.40 (C5'”), 127.59 (C4','), 128.09 (C4), 128.41 (C5'’), 129.43 (C2 and C6), 130.79 (C2'’'), 133.55 (C4' or C5'), 137.45 (C2'’), $137.83(\mathrm{C} 1), 145.66\left(\mathrm{C}^{\prime}\right.$ ) $, 169.35(\mathrm{C}=\mathrm{O} \mathrm{Ac}), 172.13(\mathrm{C}=\mathrm{O}$ ester). UV/Vis (ethanol, $\mathrm{nm})$ : $\lambda_{\max }(\log \varepsilon)=313$ (4.21). MS $m / z$ (ESI, \%): $452\left([\mathrm{M}+\mathrm{H}]^{+}, 100\right)$. HRMS: $m / z$ (ESI) calcd for $\mathrm{C}_{23} \mathrm{H}_{22} \mathrm{~N}_{3} \mathrm{O}_{3} \mathrm{~S}_{2}$ 452.10911; found 452.10971.

2.2.3. $\mathrm{N}$-acetyl-4-(4',5'-diphenyl-imidazol-2'-yl) phenylalanine methyl ester (3c). Starting from aldehyde $1\left(0.049 \mathrm{~g}, 0.160 \times 10^{-3} \mathrm{~mol}\right)$ and 1,2-diphenylethane-1,2-dione $2 \mathrm{c}(0.033 \mathrm{~g}$, $\left.0.160 \times 10^{-3} \mathrm{~mol}\right)$, compound $3 \mathrm{c}$ was isolated as an orange solid $\left(0.025 \mathrm{~g}, 0.057 \times 10^{-3} \mathrm{~mol}\right.$, $44 \%) . m p=203.1-204.2{ }^{\circ} \mathrm{C} . \mathrm{IR}\left(\mathrm{KBr} 1 \%, \mathrm{~cm}^{-1}\right): v=3320,3178,3028,1837,1751,1633$, 1596, 1525, 1418, 1382, 1368, 1300, 1290, 1254, 1222, 1166, 1100, 1085, 1059, 1029, 994, 
970, 923, 855, 812, 796, 772, 683. ${ }^{1} \mathrm{H}$ NMR (400 MHz, DMSO- $\left.d_{6}\right): \delta=1.80\left(\mathrm{~s}, 3 \mathrm{H}, \mathrm{CH}_{3}\right.$ Ac), 2.88-3.07 (m, 2H, $\left.\beta-\mathrm{CH}_{2}\right), 3.60\left(\mathrm{~s}, 3 \mathrm{H}, \mathrm{OCH}_{3}\right), 4.47-4.52(\mathrm{~m}, 1 \mathrm{H}, \alpha-\mathrm{H}), 7.19-7.49(\mathrm{~m}$, 8H, 2xPh), 7.48 (d, J 7.8 Hz, 2H, H2 and H6), 7.98 (d, J 7.8 Hz, 2H, H3 and H5), 8.36 (d, $J$ $7.6 \mathrm{~Hz}, 1 \mathrm{H}, \mathrm{NH} \mathrm{Ac}), 12.62$ (br s, $1 \mathrm{H}, \mathrm{NH}) .{ }^{13} \mathrm{C}$ NMR (100.6 MHz, DMSO-d $): \delta=22.23$ $\left(\mathrm{CH}_{3} \mathrm{Ac}\right), 36.58\left(\beta-\mathrm{CH}_{2}\right), 51.83\left(\mathrm{OCH}_{3}\right), 53.47(\alpha-\mathrm{C}), 125.11$ (C3 and $\left.\mathrm{C} 5\right), 126.50\left(\mathrm{C} 4{ }^{\prime \prime}\right)$, 127.05 (C3' ' and C5'), 127.69 (C4' or C5'), 127.74 (C4','), 128.17 (C2'” and C6'), 128.39 (C2 and C6), 128.65 (C3'"' and C5','), 128.71 (C4), 129.36 (C2',' and C6'"'), 131.07 (C1''), 135.17 (1','), 137.03 (C4' or C5'), 137.40 (C1), 145.44 (C2'), 169.35 (C=O Ac), 172.16 $(\mathrm{C}=\mathrm{O}$ ester). UV/Vis (ethanol, $\mathrm{nm}): \lambda_{\max }(\log \varepsilon)=304$ (4.28). MS $\mathrm{m} / z$ (ESI, \%): 440 $\left([\mathrm{M}+\mathrm{H}]^{+}, 100\right)$. HRMS: $m / z$ (ESI) calcd for $\mathrm{C}_{27} \mathrm{H}_{26} \mathrm{~N}_{3} \mathrm{O}_{3} 440.19687$; found 440.19628 .

\subsection{4. $N$-acetyl-4-(4',5'-di(pyridin-2''-yl)imidazol-2'-yl) phenylalanine methyl ester (3d).}

Starting from aldehyde $1\left(0.020 \mathrm{~g}, 0.066 \times 10^{-3} \mathrm{~mol}\right)$ and 1,2-di(pyridin-2-yl)ethane-1,2dione $2 \mathbf{d}\left(0.014 \mathrm{~g}, 0.066 \times 10^{-3} \mathrm{~mol}\right)$, compound 3d was isolated as an orange solid $(0.020 \mathrm{~g}$, $\left.0.045 \times 10^{-3} \mathrm{~mol}, 44 \%\right) . \mathrm{mp}=123.9-124.7^{\circ} \mathrm{C} . \mathrm{IR}\left(\operatorname{KBr} 1 \%, \mathrm{~cm}^{-1}\right): v=3351,3068,2918$, 1764, 1691, 1632, 1526, 1509, 1437, 1365, 1320, 1293, 1256, 1166, 1109, 1086, 1049, 1019, 991, 920, 853, 812, 796, 772, 684. ${ }^{1} \mathrm{H}$ NMR (400 MHz, $\mathrm{CDCl}_{3}$ ): $\delta=1.96$ (s, 3H, $\mathrm{CH}_{3} \mathrm{Ac}$ ), 3.04-3.17 (m, 2H, $\left.\beta-\mathrm{CH}_{2}\right), 3.69$ (s, 3H, $\left.\mathrm{OCH}_{3}\right), 4.83-4.88(\mathrm{~m}, 1 \mathrm{H}, \alpha-\mathrm{H}), 6.04(\mathrm{~d}, J 7.6 \mathrm{~Hz}$, 1H, NH Ac), 7.11-7.14 (m, 2H, $2 \times \mathrm{H} 5$ '”), 7.13 (d, J 8.0, 2H, H2 and H6), 7.72 (t, $J 7.3 \mathrm{~Hz}$, $2 \mathrm{H}, 2 \times \mathrm{H} 4$ ' '), 8.02 (d, J 7.3 Hz, 2H, $2 \times \mathrm{H} 3$ '’), 8.44-8.46 (m, 2H, H3 and H5), 8.64 (d, J 4.0 $\left.\mathrm{Hz}, 2 \mathrm{H}, 2 \times \mathrm{H}^{\prime \prime}{ }^{\prime}\right) .{ }^{13} \mathrm{C} \mathrm{NMR}\left(100.6 \mathrm{MHz}, \mathrm{CDCl}_{3}\right): \delta=23.16\left(\mathrm{CH}_{3} \mathrm{Ac}\right), 37.79\left(\beta-\mathrm{CH}_{2}\right), 52.44$ $\left(\mathrm{OCH}_{3}\right), 53.14(\alpha-\mathrm{C}), 122.59$ (C3'”), 123.37 (C3 and C5), 126.46 (C5'), $127.88(\mathrm{C} 4), 127.95$ (C4' and C5'), 129.64 (C2 and C6), 137.38 (C1), 138.52 (C4'), 146.64 (C6'), 147.32 (C2'), 149.13 (C2'), 169.75 (C=O Ac), 171.91 (C=O ester). UV/Vis (ethanol, $\mathrm{nm}$ ): $\lambda_{\max }$ (log $\varepsilon)=307$ (4.25). MS m/z (ESI, \%): $442\left([\mathrm{M}+\mathrm{H}]^{+}, 100\right)$. HRMS: $m / z$ (ESI) calcd for $\mathrm{C}_{25} \mathrm{H}_{24} \mathrm{~N}_{5} \mathrm{O}_{3} 442.18737$; found 442.18648 .

\subsection{Spectrophotometric and spectrofluorimetric titrations and chemosensing studies for imidazolyl-phenylalanines 3a-d}

UV-visible absorption spectra (200-700 nm) were obtained using a Shimadzu UV/2501PC spectrophotometer. Fluorescence spectra were collected using a FluoroMax-4 spectrofluorometer. Organic solvents used in the spectroscopic studies were of spectroscopic grade. Relative fluorescence quantum yields were calculated using 9,10-diphenylanthracene 
as standard $\left(\Phi_{\mathrm{F}}=0.95\right.$ in ethanol) [14]. The linearity of the absorption versus concentration was checked within the used concentration.

Solutions of imidazolyl-phenylalanines 3a-d (ca. $1.0 \times 10^{-5}$ to $1.0 \times 10^{-6} \mathrm{M}$ ) and of the ions under study (ca. $1.0 \times 10^{-1}$ to $1.0 \times 10^{-3} \mathrm{M}$ ) (in the form of hydrated tetrafluorborate salts for $\mathrm{Cu}^{+}, \mathrm{Ag}^{+}, \mathrm{Pd}^{2+}$ and $\mathrm{Co}^{2+}$, hydrated perchlorate salts for $\mathrm{K}^{+}, \mathrm{Cd}^{2+}, \mathrm{Ca}^{2+}, \mathrm{Fe}^{3+}, \mathrm{Fe}^{2+}, \mathrm{Cr}^{3+}, \mathrm{Cu}^{2+}$, $\mathrm{Ni}^{2+}, \mathrm{Cs}^{+}, \mathrm{Na}^{+}, \mathrm{Hg}^{2+}, \mathrm{Pb}^{2+}, \mathrm{Zn}^{2+}$ and hydrated tetrabutylammonium salts for $\mathrm{CH}_{3} \mathrm{COO}^{-}, \mathrm{F}^{-}, \mathrm{Cl}^{-}$ , $\mathrm{Br}^{-}, \mathrm{I}^{-}, \mathrm{ClO}_{4}^{-}, \mathrm{CN}^{-}, \mathrm{NO}_{3}^{-}, \mathrm{BzO}^{-}$and $\mathrm{OH}^{-}$) were prepared in $\mathrm{UV}$-grade acetonitrile or acetonitrile/water (80:20). Titration of the compounds with the several ions was performed by the sequential addition of ion stock solution to the phenylalanine solution, in a $10 \mathrm{~mm}$ path length quartz cuvette and emission spectra were measured by excitation at the wavelength of maximum absorption for each compound, with a $2 \mathrm{~nm}$ slit. The association constants and the binding stoichiometry were obtained with HypSpec software.

\section{Results and discussion}

\subsection{Synthesis of 4,5-diarylimidazolyl-phenylalanines 3a-d}

Novel 4,5-diarylimidazolyl-phenylalanines 3a-d were synthesised by reaction of $\mathrm{N}$-tertbutyloxycarbonyl-4-formylphenylalanine methyl ester $\mathbf{1}$ with the appropriate aromatic dione 2a-d, through a Radziszewski reaction in the presence of ammonium acetate in acetic acid at reflux for 2 hours [15]. The pure compounds were isolated, after chromatography, in moderate yield (42-45\%) and were characterized by the usual spectroscopic techniques. The acidic reaction media yielded the $\mathrm{N}$-acetylated form of the amino acids, by substitution of the starting $N$-tert-butyloxycarbonyl (Boc) group (Scheme 1, Table 1). The synthesized amino acids are L-amino acids as the precursor $\mathbf{1}$ had L-configuration and no evidence was found for the loss of the integrity of the chiral centre in these reaction conditions by NMR. 


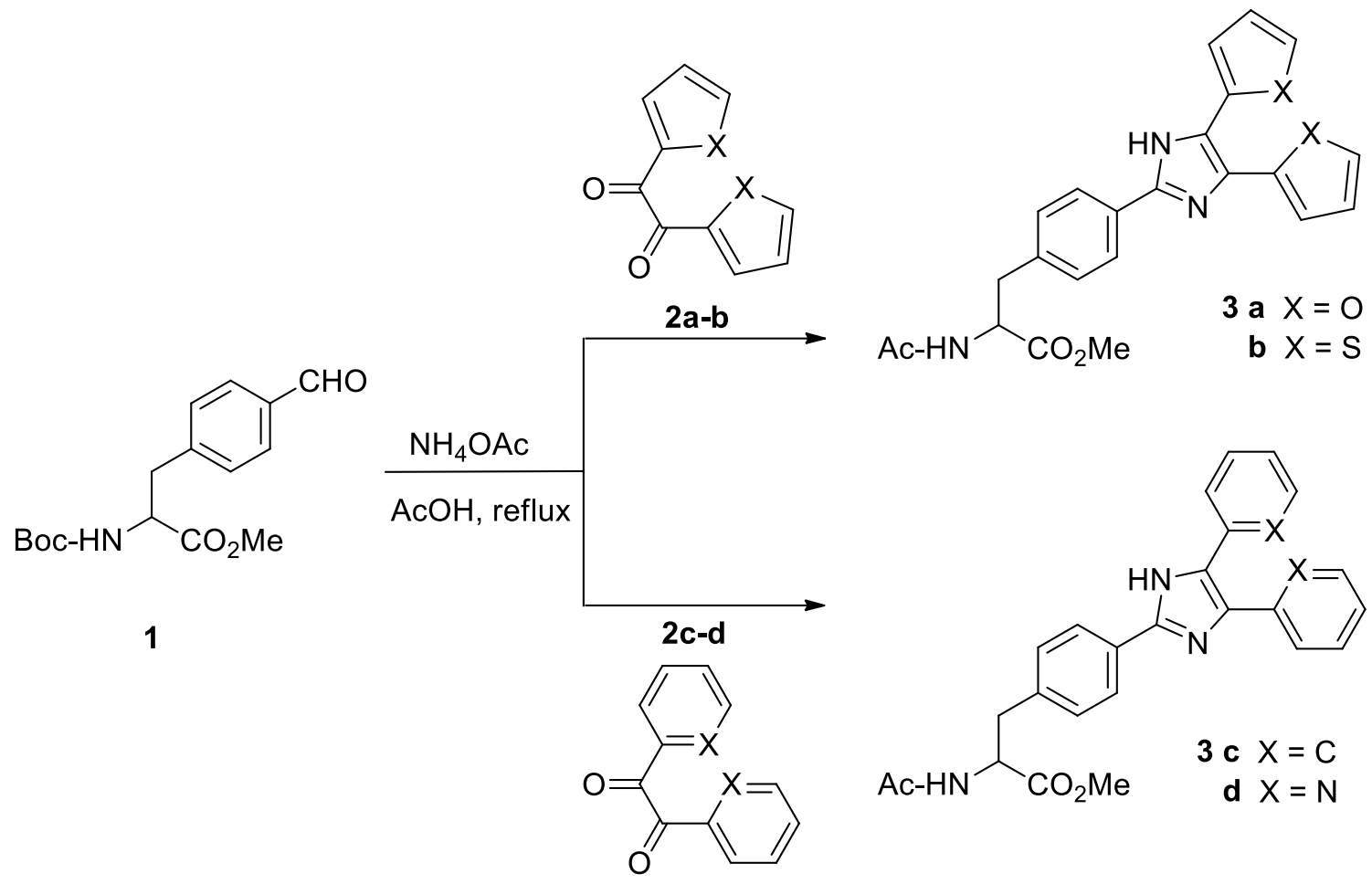

Scheme. Synthesis of 4,5-diarylimidazolyl-phenylalanines 3a-d.

Table 1. Yields, UV-visible absorption and fluorescence data for 4,5-diarylimidazolylphenylalanines 3a-d in absolute ethanol ([3a-d $\left.]=10^{-6}-10^{-5} \mathrm{M}\right)$.

\begin{tabular}{cccccccc}
\hline & Yield & \multicolumn{3}{c}{ UV/Vis } & \multicolumn{5}{c}{ Fluorescence } \\
\cline { 3 - 8 } Compound & \begin{tabular}{c} 
(\%) \\
\cline { 3 - 7 }
\end{tabular} & $\lambda_{\text {abs }(\mathrm{nm})}$ & $\log \varepsilon$ & $\lambda_{\mathrm{em}}(\mathrm{nm})$ & $\begin{array}{c}\text { Stokes' } \\
\text { shift }(\mathrm{nm})\end{array}$ & $\begin{array}{c}\text { Stokes' } \\
\text { shift }\left(\mathrm{cm}^{-1}\right)\end{array}$ & $\Phi_{\mathrm{F}}$ \\
\hline 3a & 42 & 317 & 4.21 & 405 & 88 & 6854 & 0.72 \\
3b & 45 & 313 & 4.21 & 420 & 107 & 8139 & 0.26 \\
3c & 44 & 304 & 4.28 & 382 & 78 & 6717 & 0.42 \\
3d & 44 & 307 & 4.25 & 426 & 119 & 9099 & 0.14 \\
\hline
\end{tabular}

\subsection{Photophysical study of 4,5-diarylimidazolyl-phenylalanines 3a-d}

The photophysical properties of phenylalanines 3a-d were evaluated and the UV-vis absorption and fluorescence spectra of degassed $10^{-6}-10^{-5} \mathrm{M}$ solutions in absolute ethanol were measured (Table 1). Compounds 3a-d displayed absorption and emission maxima at longer wavelengths ( $\lambda_{\mathrm{abs}}$ and $\lambda_{\mathrm{em}}$, respectively), when compared with the unsubstituted phenylalanine in the same solvent $\left(\lambda_{\mathrm{abs}}=258 \mathrm{~nm}\right.$ and $\left.\lambda_{\mathrm{em}}=280 \mathrm{~nm}\right)$, a fact related to the 
nature of the pendant groups which resulted in extended intramolecular electron delocalization and a higher push-pull character of the whole system. In fact, the position of the red shifted absorption bands were clearly dependent on the electron donor strength of the (hetero) aromatic group at positions 4 and 5 of the imidazole: for 3a, bearing a phenyl group (the least electron donor), the absorption band was centred at $304 \mathrm{~nm}$. On changing to electron-deficient pyridyl-derivative (3d), the absorption maximum suffered a very slight bathochromic shift to $307 \mathrm{~nm}$, whereas when heterocyclic electron donors such as furan (3a) or thiophene (3b) were present, the red shift was larger to 317 and $313 \mathrm{~nm}$, respectively. 4,5Diarylimidazolyl-phenylalanines 3a-d showed modest to high relative fluorescence quantum yields, between 0.14 (3d) and 0.72 (3a), and displayed large Stokes' shifts. A large Stokes' shift is an interesting characteristic for a fluorescent probe that allows an improved separation of the light inherent to the matrix and the light dispersed by the sample.

Considering the results obtained in ethanol, the photophysical properties of phenyalanines 3a-d were evaluated in other organic solvents of different character. The solvents tested were acetonitrile, dimethylsulfoxide, dichloromethane and diethyl ether, as examples of solvents with different polarity and proticity, with $\pi^{*}$ values by Kamlet and Taft [16]. The collected data revealed similar wavelengths of maximum absorption and emission and the fluorescence quantum yield did not vary significantly (Table 2). The overall trend revealed that phenylalanine 3a with furyl pendants was the most fluorescent (with $\Phi_{\mathrm{F}}$ in the range 0.640.77) whereas phenylalanine $\mathbf{3 b}$ bearing thienyl pendants displayed the largest Stokes' shifts (between 105-109 nm).

Table 2. UV-visible absorption and emission data for 4,5-diarylimidazolyl-phenylalanines 3a-d in organic solvents of different character, with $\pi^{*}$ values by Kamlet and Taft [16].

\begin{tabular}{|c|c|c|c|c|c|c|c|}
\hline \multirow[b]{2}{*}{ Cpd. } & \multirow[b]{2}{*}{$\begin{array}{c}\text { Solvent } \\
\left(\pi^{*}\right)\end{array}$} & \multicolumn{3}{|l|}{ UV/Vis } & \multicolumn{3}{|c|}{ Fluorescence } \\
\hline & & $\lambda_{\mathrm{abs}}$ & $\log \varepsilon$ & $\lambda_{\mathrm{em}}$ & $\begin{array}{c}\text { Stokes' } \\
\text { shift }(\mathrm{nm})\end{array}$ & $\begin{array}{c}\text { Stokes' } \\
\operatorname{shift}\left(\mathrm{cm}^{-1}\right)\end{array}$ & $\Phi_{\mathrm{F}}$ \\
\hline \multirow{4}{*}{$3 \mathbf{a}$} & Diethyl ether (0.27) & 313 & 4.23 & 401 & 88 & 7011 & 0.76 \\
\hline & EtOH (0.54) & 317 & 4.21 & 405 & 88 & 6854 & 0.72 \\
\hline & $\operatorname{ACN}(0.75)$ & 317 & 4.24 & 413 & 96 & 7333 & 0.77 \\
\hline & DCM $(0.82)$ & 324 & 4.21 & 410 & 86 & 6474 & 0.64 \\
\hline
\end{tabular}




\begin{tabular}{|c|c|c|c|c|c|c|c|}
\hline & DMSO (1.00) & 317 & 4.26 & 409 & 92 & 7096 & 0.64 \\
\hline \multirow{5}{*}{$3 \mathbf{b}$} & Diethyl ether (0.27) & 312 & 4.23 & 419 & 107 & 8185 & 0.29 \\
\hline & $\mathrm{EtOH}(0.54)$ & 313 & 4.21 & 420 & 107 & 8139 & 0.26 \\
\hline & $\operatorname{ACN}(0.75)$ & 313 & 4.28 & 422 & 109 & 8252 & 0.30 \\
\hline & $\operatorname{DCM}(0.82)$ & 318 & 4.25 & 423 & 105 & 7806 & 0.26 \\
\hline & DMSO (1.00) & 320 & 4.29 & 428 & 108 & 7886 & 0.14 \\
\hline \multirow{5}{*}{$3 \mathbf{c}$} & Diethyl ether (0.27) & 309 & 4.27 & 383 & 74 & 6253 & 0.44 \\
\hline & $\mathrm{EtOH}(0.54)$ & 304 & 4.28 & 382 & 78 & 6717 & 0.42 \\
\hline & $\operatorname{ACN}(0.75)$ & 305 & 4.30 & 383 & 78 & 6677 & 0.46 \\
\hline & $\operatorname{DCM}(0.82)$ & 309 & 4.27 & 383 & 74 & 6253 & 0.43 \\
\hline & DMSO (1.00) & 312 & 4.31 & 391 & 79 & 6476 & 0.20 \\
\hline \multirow{5}{*}{ 3d } & Diethyl ether (0.27) & 306 & 4.25 & 388 & 82 & 6907 & 0.10 \\
\hline & $\mathrm{EtOH}(0.54)$ & 307 & 4.25 & 426 & 119 & 9099 & 0.14 \\
\hline & $\mathrm{ACN}(0.75)$ & 305 & 4.25 & 398 & 93 & 7661 & 0.14 \\
\hline & DCM $(0.82)$ & 307 & 4.25 & 394 & 87 & 7193 & 0.14 \\
\hline & DMSO (1.00) & 310 & 4.25 & 399 & 89 & 7092 & 0.13 \\
\hline
\end{tabular}

As the chemosensing study towards different ions was carried out in acetonitrile and acetonitrile/water (80:20), the absorption and emission spectra of 4,5-diarylimidazolylphenylalanines 3a-d were also measured in these mixtures at different $\mathrm{pH}\left(10^{-6}-10^{-5} \mathrm{M}\right.$ solution). Buffer systems used were sodium acetate $0.1 \mathrm{M}$ /acetic acid $0.1 \mathrm{M}$ for $\mathrm{pH}=4$, potassium hydrogenphosphate $0.1 \mathrm{M}$ /sodium hydroxide $0.1 \mathrm{M}$ for $\mathrm{pH}=7$ and sodium hydrogencarbonate $0.05 \mathrm{M}$ /sodium hydroxide $0.1 \mathrm{M}$ for $\mathrm{pH}=10$. For every compound, there was a bathochromic shift of both wavelengths of maximum absorption and emission on going from acidic to basic $\mathrm{pH}$, probably indicative of a certain degree of deprotonation at the imidazole NH which in turn lead to a higher charge density at the heterocycle that could be delocalised through the system (Figure 1, for phenylalanine $\mathbf{3 b}$ as representative example). However, the increase in $\mathrm{pH}$ was accompanied by a decrease of the relative fluorescence quantum yields (except for phenylalanine 3d which was practically non fluorescent in aqueous solution (Table 3). 


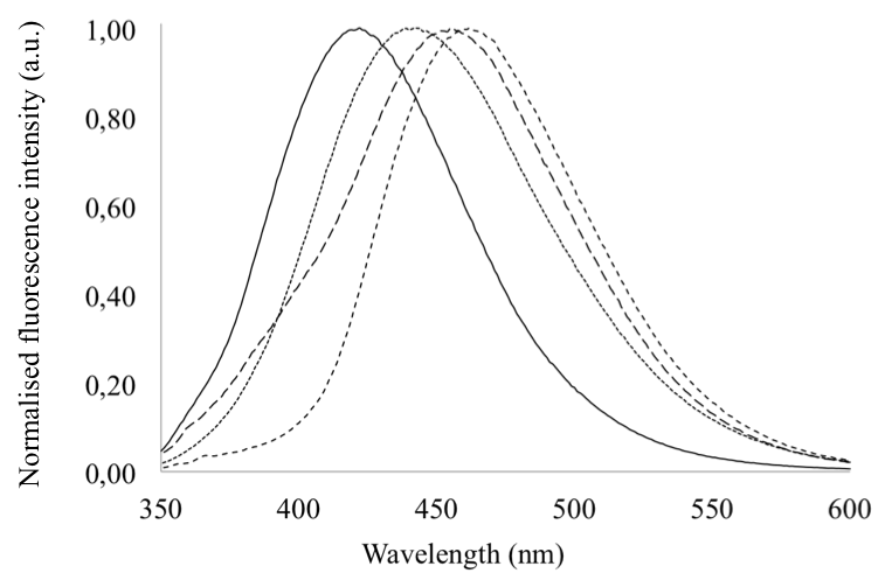

Figure 1. Normalised fluorescence spectra of 4,5-di(thiophen-2'-yl)imidazolyl-phenylalanine $3 \mathbf{b}$ in $\mathrm{ACN}(-)$ and $\mathrm{ACN} / \mathrm{H}_{2} \mathrm{O}(80: 20)$ buffered at $\mathrm{pH}=4$ in (..), $\mathrm{pH}=7$ (..-) and $\mathrm{pH}=10$ (--) $\left([3 \mathbf{b}]=6.7 \times 10^{-6} \mathrm{M}\right)$.

Table 3. UV-visible absorption and emission data for 4,5-diarylimidazolyl-phenylalanines 3a-d in $\mathrm{ACN} / \mathrm{H}_{2} \mathrm{O}(80: 20)$ buffered at different $\mathrm{pH}\left([\mathbf{3 a}-\mathbf{d}]=10^{-6}-10^{-5} \mathrm{M}\right)$.

\begin{tabular}{|c|c|c|c|c|c|c|c|}
\hline \multirow[b]{2}{*}{ Compound } & \multirow[b]{2}{*}{$\mathrm{pH}$} & \multicolumn{3}{|l|}{ UV/Vis } & \multicolumn{3}{|c|}{ Fluorescence } \\
\hline & & $\lambda_{\max }(\mathrm{nm})$ & $\log \varepsilon$ & $\lambda_{\max }(\mathrm{nm})$ & $\begin{array}{c}\text { Stokes' } \\
\text { shift (nm) }\end{array}$ & $\begin{array}{c}\text { Stokes' } \\
\text { shift }\left(\mathrm{cm}^{-1}\right)\end{array}$ & $\Phi_{\mathrm{F}}$ \\
\hline \multirow{3}{*}{$\mathbf{3 a}$} & 4 & 312 & 4.22 & 410 & 98 & 7661 & 0.75 \\
\hline & 7 & 324 & 4.23 & 416 & 92 & 6826 & 0.62 \\
\hline & 10 & 329 & 4.21 & 422 & 93 & 6698 & 0.55 \\
\hline \multirow{3}{*}{$3 \mathbf{b}$} & 4 & 310 & 4.23 & 442 & 132 & 9634 & 0.25 \\
\hline & 7 & 325 & 4.23 & 455 & 130 & 8791 & 0.20 \\
\hline & 10 & 330 & 4.23 & 462 & 132 & 8658 & 0.18 \\
\hline \multirow{3}{*}{$3 c$} & 4 & 295 & 4.27 & 396 & 101 & 8646 & 0.46 \\
\hline & 7 & 305 & 4.29 & 408 & 103 & 8277 & 0.35 \\
\hline & 10 & 318 & 4.26 & 428 & 110 & 8082 & 0.23 \\
\hline \multirow{3}{*}{ 3d } & 4 & 300 & 4.26 & 415 & 115 & 9237 & 0.02 \\
\hline & 7 & 305 & 4.25 & 400 & 96 & 7895 & 0.05 \\
\hline & 10 & 309 & 4.25 & 397 & 86 & 7174 & 0.04 \\
\hline
\end{tabular}




\subsection{Spectrofluorimetric titrations of 4,5-diarylimidazolyl-phenylalanines 3a-d with ions}

The modification of phenylalanine through the introduction of extra UV-absorbing and fluorescent heterocycles at its side chain was expected to provide additional binding sites for a variety of ions through the heterocycle donor atoms, as well as improved photophysical properties for the chemosensing studies. It was also intended to assess the influence of the structure in the chemosensing ability of anions and cations.

Evaluation of new 4,5-diarylimidazolyl-phenylalanines 3a-d as fluorimetric chemosensors was carried out by performing spectrophotometric and spectrofluorimetric titrations in ACN and $\mathrm{ACN} / \mathrm{H}_{2} \mathrm{O}$ (80:20), in the presence of organic and inorganic anions, and of alkaline, alkaline-earth and transition metal cations $\left(\mathrm{AcO}^{-}, \mathrm{F}^{-}, \mathrm{Cl}^{-}, \mathrm{Br}^{-}, \mathrm{I}^{-}, \mathrm{ClO}_{4}^{-}, \mathrm{CN}^{-}, \mathrm{NO}_{3}^{-}, \mathrm{BzO}^{-}, \mathrm{OH}^{-}\right.$ $\mathrm{H}_{2} \mathrm{PO}_{4}^{-}, \mathrm{HSO}_{4}^{-}, \mathrm{Na}^{+}, \mathrm{K}^{+}, \mathrm{Cs}^{+}, \mathrm{Ag}^{+}, \mathrm{Cu}^{+}, \mathrm{Cu}^{2+}, \mathrm{Ca}^{2+}, \mathrm{Cd}^{2+}, \mathrm{Co}^{2+}, \mathrm{Pb}^{2+}, \mathrm{Pd}^{2+}, \mathrm{Ni}^{2+}, \mathrm{Hg}^{2+}, \mathrm{Zn}^{2+}$, $\mathrm{Fe}^{2+}, \mathrm{Fe}^{3+}$ and $\left.\mathrm{Cr}^{3+}\right)$, with biological, environmental and analytical relevance.

A preliminary test was carried out by addition of up to 100 equiv of each ion to the solutions of phenylalanines 3a-d. No noticeable changes occurred in the colour of the solutions but significant changes were visible in the fluorescence intensity upon interaction with some ions, such as $\mathrm{Cu}^{2+}, \mathrm{Fe}^{3+}, \mathrm{F}^{-}$and $\mathrm{OH}^{-}$.

Therefore, spectrofluorimetric titrations of phenylalanines 3a-d in acetonitrile with $\mathrm{Cu}^{2+}$, $\mathrm{Fe}^{3+}, \mathrm{F}^{-}$and $\mathrm{OH}^{-}$were carried out. With $\mathrm{Cu}^{2+}$ a decrease of the fluorescence intensity (a chelation enhanced quenching effect, CHEQ) was observed with a complete fluorescence quenching. In Figure 2A, as representative example, is shown the spectrofluorimetric titration of phenylalanine 3a with $\mathrm{Cu}^{2+}$, where the drastic effect of cation complexation is evident in the band of maximum emission centred at $317 \mathrm{~nm}$, with 10 equiv of cation being sufficient for the complete quenching (Figure 2A). The quenching effect in the presence of $\mathrm{Cu}^{2+}$ can be attributed to an energy transfer quenching of the $\pi^{*}$ emissive state through low-lying metalcentered unfilled $d$-orbitals [5e]. This result suggests the involvement of the metal ion with donor atoms, the $\mathrm{N}$ from the imidazole and the $\mathrm{O}$ or $\mathrm{S}$ from the pendant furan or thiophene.

With regard to the other ions, with $\mathrm{Fe}^{3+}$ a pronounced CHEQ effect was also observed after ion addition (with 15 equiv), accompanied by a red shift of the emission band, whereas with $\mathrm{F}^{-}$and $\mathrm{OH}^{-}$an incomplete quenching of fluorescence (ca. $70 \%$, about 20 equiv to achieve the plateau) was seen. In Figures 2 B, C and D are shown the spectrofluorimetric titrations of phenylalanine 3a with $\mathrm{Fe}^{3+}, \mathrm{F}^{-}$and $\mathrm{OH}^{-}$, respectively. These anions also induced a quenching of the fluorescence band that could be ascribed to a proton transfer process that yields the deprotonated probe [5b]. 
As for 4,5-diarylimidazolyl-phenylalanines 3b-d, the spectrofluorimetric titrations in acetonitrile with $\mathrm{Fe}^{3+}$ resulted in a complete quenching with the addition of 180, 280 and 0.35 metal equiv, respectively. Also, titration with both anions induced a similar incomplete fluorescence quenching after addition of 10 equiv of $\mathrm{F}^{-}$or $\mathrm{OH}^{-}$(of about $75 \%$ for $\mathbf{3 b}, 45 \%$ for 3c and 40\% for 3d). Overall, 4,5-di(furan-2'-yl)imidazolyl-phenylalanine 3a and 4,5di(thiophen-2'-yl)imidazolyl-phenylalanine $\mathbf{3 b}$ were the most sensitive towards $\mathrm{Cu}^{2+}$ and $\mathrm{Fe}^{3+}$, with phenylalanine 3a being the most interesting candidate as chemosensor due to the higher fluorescence quantum yield, which is important for maximization of response to analyte in the analysis of very dilute samples. On the other hand, the very low original fluorescence of 4,5-di(pyridin-2'-yl)imidazolyl-phenylalanine 3d precluded its application as a fluorimetric chemosensor, although it was extremely sensitive to $\mathrm{Cu}^{2+}$ and $\mathrm{Fe}^{3+}$ with complete quenching after addition of 1.5 and 0.35 equiv of metal, respectively.
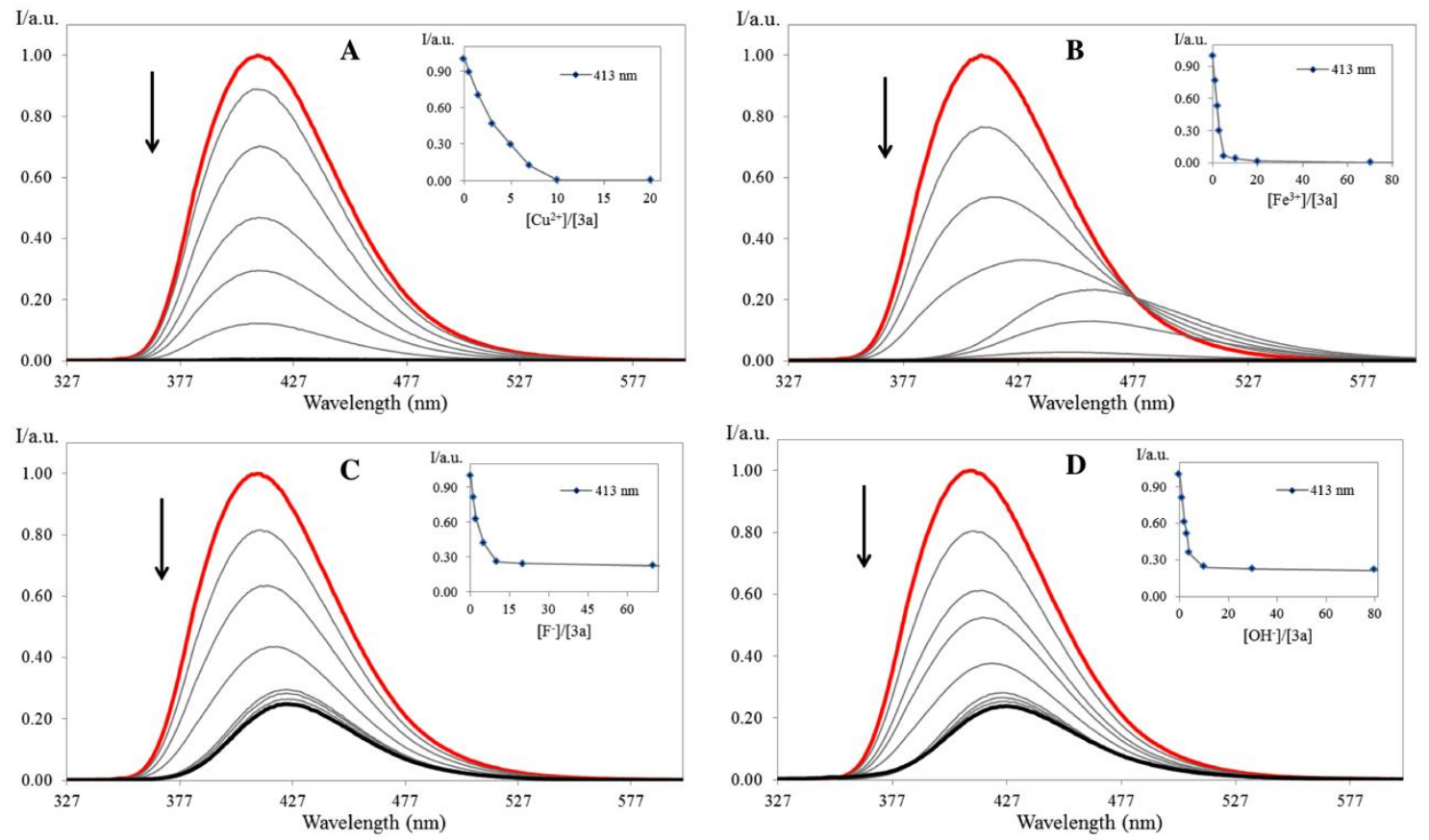

Figure 2. Fluorimetric titrations of 4,5-di(furan-2'-yl)imidazolyl-phenylalanine 3a with $\mathrm{Cu}^{2+}$ $(\mathrm{A}), \mathrm{Fe}^{3+}(\mathrm{B}), \mathrm{F}^{-}(\mathrm{C})$ and $\mathrm{OH}^{-}(\mathrm{D})$ in acetonitrile $\left[\lambda_{\text {exc }} \mathbf{3 a}=317 \mathrm{~nm},[\mathbf{3 a}]=7.2 \times 10^{-6} \mathrm{M}\right.$, the cations in the form of perchlorate salts and the anions in the form of tetrabutylammonium salts]. Inset: normalised emission at $413 \mathrm{~nm}$ as a function of added ion equivalents. 
Having in mind practical applications of compounds 3a-d in aqueous media, the chemosensory ability was also evaluated in mixtures of acetonitrile and water in varying proportions. The best results, considering a compromise of fluorescence intensity and compound solubility, were obtained in acetonitrile/ $\mathrm{H}_{2} \mathrm{O}(80: 20, \mathrm{v} / \mathrm{v})$. The study of the same ions described before in organic aqueous solution lead to lower detection sensitivity since it was necessary to increase the number of equivalents of cation to obtain a similar quenching response, and the fluorescence was not affected in the case of the interaction with $\mathrm{F}^{-}$and $\mathrm{OH}^{-}$. In the case of $\mathrm{Cu}^{2+}$ and $\mathrm{Fe}^{3+}$, higher sensitivity was obtained for the latter cation in aqueous acetonitrile. In Figure 3, it is compared the behaviour of phenylalanines $\mathbf{3 a - b}$ with $\mathrm{Fe}^{3+}$ in $\mathrm{ACN}$ and $\mathrm{ACN} / \mathrm{H}_{2} \mathrm{O}(80: 20)$ and in Figure 4 it is presented the interaction between phenylalanines 3c-d with $\mathrm{Fe}^{3+}$ in $\mathrm{ACN}$ and $\mathrm{ACN} / \mathrm{H}_{2} \mathrm{O}$ (80:20). In all cases, the interaction with $\mathrm{Fe}^{3+}$ resulted in a red shift of the emission band and for phenylalanine $\mathbf{3 b}$ the initial amount of cation added caused an increase of the fluorescence intensity (a chelation enhancement of fluorescence, $\mathrm{CHEF}$ effect) which reverted to the quenching as the addition continued.
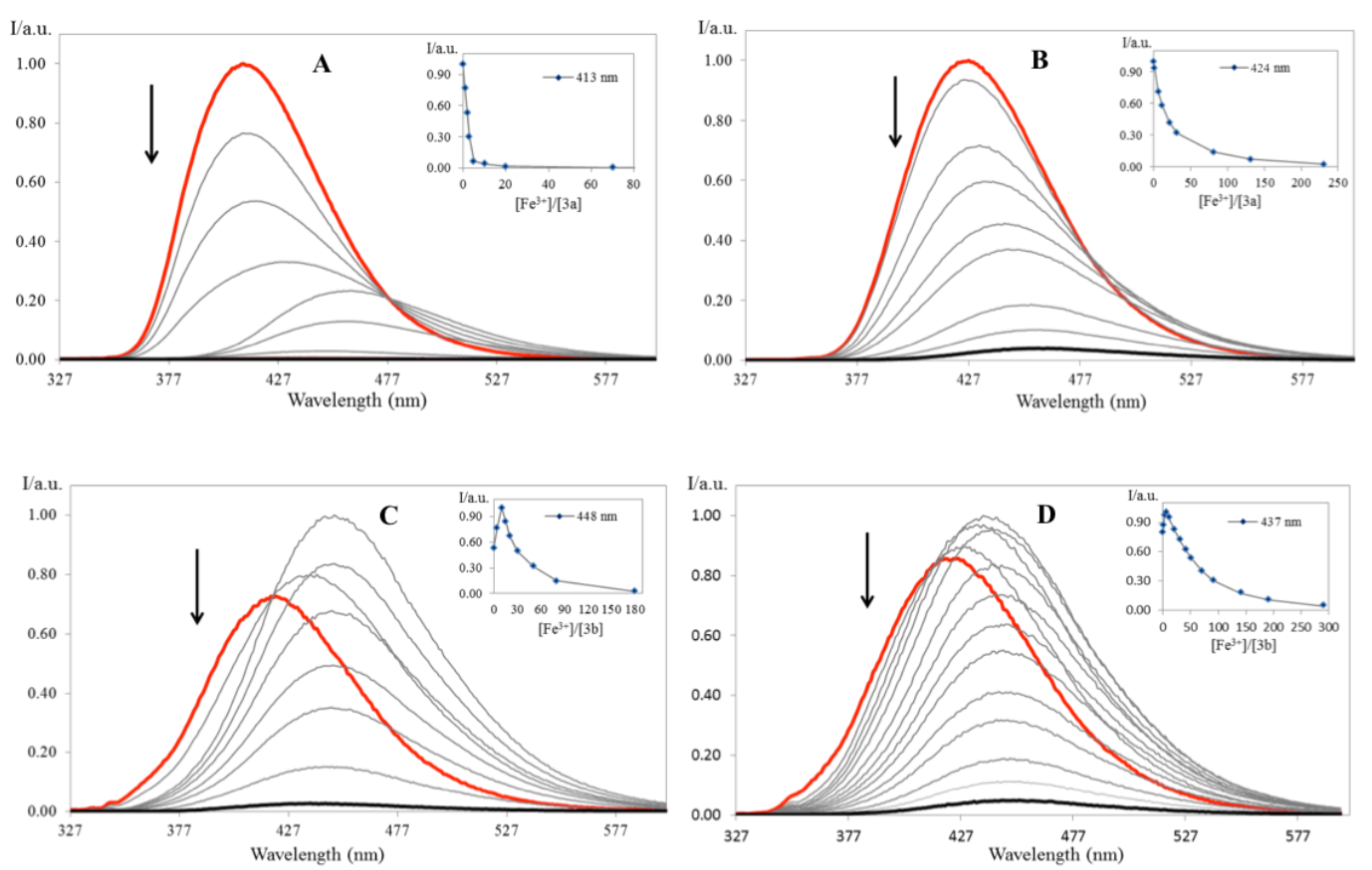

Figure 3. Fluorimetric titrations of 4,5-di(furan-2'-yl)imidazolyl-phenylalanine 3a with $\mathrm{Fe}^{3+}$ in $\mathrm{ACN}$ (A) and with $\mathrm{Fe}^{3+}$ in $\mathrm{ACN} / \mathrm{H}_{2} \mathrm{O}$ (80:20, pH 7) (B), and 4,5-di(thiophen-2'yl)imidazolyl-phenylalanine $3 \mathbf{b}$ with $\mathrm{Fe}^{3+}$ in $\mathrm{ACN}(\mathrm{C})$ and with $\mathrm{Fe}^{3+}$ in $\mathrm{ACN} / \mathrm{H}_{2} \mathrm{O}$ (80:20, pH 7) (D), $\left[\lambda_{\text {exc }} 3 \mathbf{a}=317 \mathrm{~nm},[\mathbf{3 a}]=7.2 \times 10^{-6} \mathrm{M} ; \lambda_{\operatorname{exc}} \mathbf{3 b}=313 \mathrm{~nm},[\mathbf{3 b}]=6.7 \times 10^{-6} \mathrm{M}\right.$, the cation 
in the form of perchlorate salt]. Inset: normalised emission at the wavelength of maximum emission as a function of added ion equivalents.
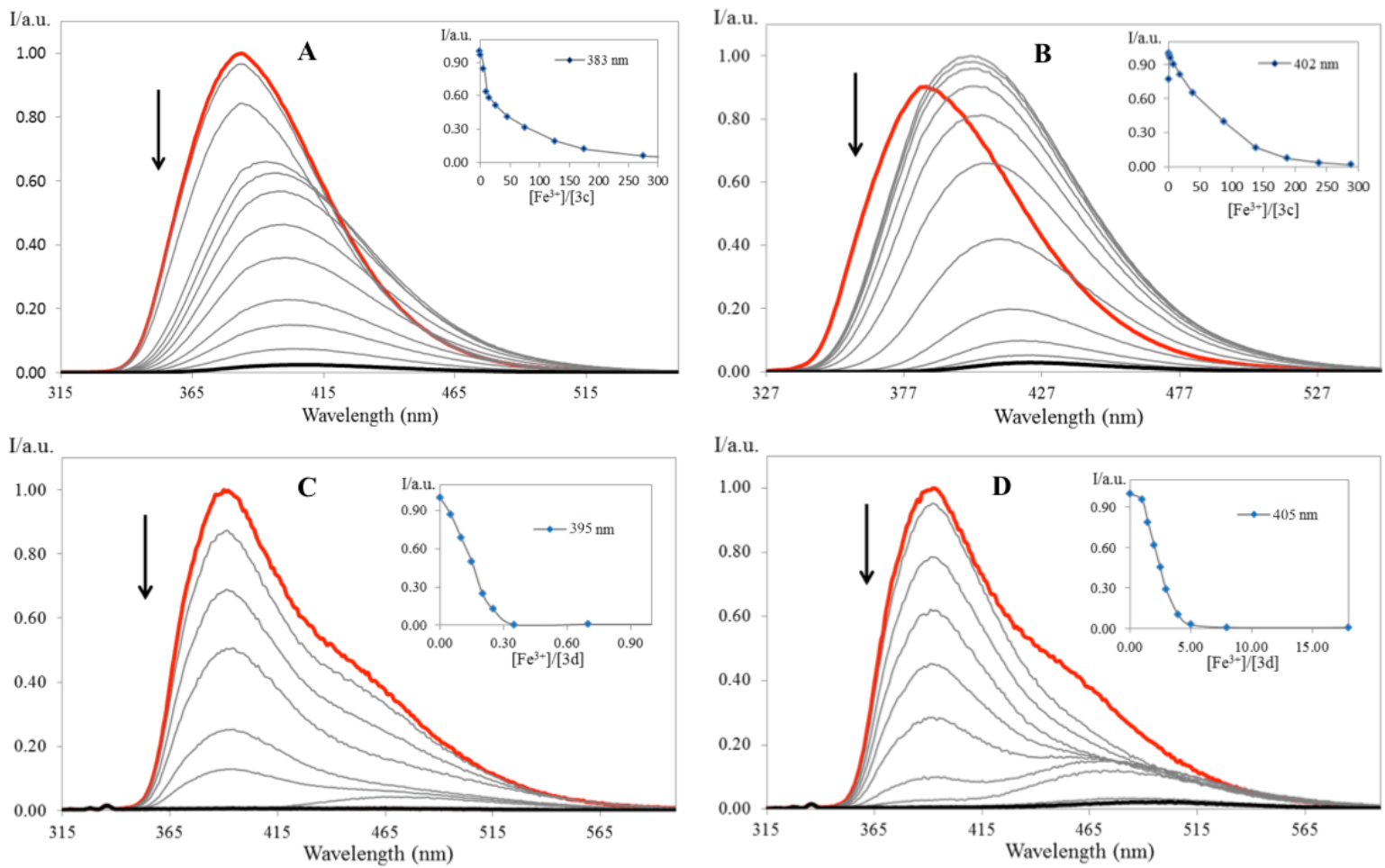

Figure 4. Fluorimetric titrations of 4,5-diphenylimidazolyl-phenylalanine $3 \mathbf{c}$ with $\mathrm{Fe}^{3+}$ in $\mathrm{ACN}$ (A) and with $\mathrm{Fe}^{3+}$ in $\mathrm{ACN} / \mathrm{H}_{2} \mathrm{O}(80: 20, \mathrm{pH}$ 7) (B), and 4,5-di(pyridin-2'-yl)imidazolylphenylalanine 3d with $\mathrm{Fe}^{3+}$ in $\mathrm{ACN}(\mathrm{C})$ and with $\mathrm{Fe}^{3+}$ in $\mathrm{ACN} / \mathrm{H}_{2} \mathrm{O}(80: 20, \mathrm{pH} 7)$ (D), $\left[\lambda_{\text {exc }}\right.$ $\mathbf{3 c}, \mathbf{d}=305 \mathrm{~nm},[\mathbf{3 c}]=[\mathbf{3 d}]=6.8 \times 10^{-6} \mathrm{M}$, the cation in the form of perchlorate salt $]$. Inset: normalised emission at the wavelength of maximum emission as a function of added ion equivalents.

Previous studies suggested that the free amino acid terminals did not influence significantly the coordination and that it should preferably occur through the heteroatoms at the side chain of the amino acid [12e]. Also, our previous work in synthetic fluorescent amino acids indicated that these amino acids maintain their sensing ability when incorporated into small sequences and, therefore, the resulting peptides displayed sensing ability as well [9a].

\section{4. ${ }^{1} \mathrm{H}$ NMR titrations for compound $3 b$}

In order to elucidate the binding mode, ${ }^{1} \mathrm{H}$ NMR titrations were carried out in DMSO- $d_{6}$ for compound $\mathbf{3 b}$ with $\mathrm{F}^{-}$and $\mathrm{Cu}^{2+}$, as representative examples, due to insolubility of compound 
3b in deuterated acetonitrile in the required concentration. These titrations revealed that the coordination site involved the imidazole and thiophene, as the signals for these two moieties were more altered upon anion/cation addition (Figures 5 and 6). The signal of the imidazole NH appearing downfield suggested high acidity and strong hydrogen-bonding ability. In more detail, upon addition of $\mathrm{F}^{-}$only 1 equiv of the ion to ensure complete deprotonation of the imidazole $\mathrm{NH}$ and both thiophene rings become equivalent and only one set of proton signals was visible. Deprotonation caused an increase in the electron density in the imidazole ring, which in turn induced a shielding effect on the neighbouring thiophene and phenyl rings owing to through-bond effects. With increasing amounts of $\mathrm{F}^{-}$, the thiophene protons $\mathrm{H} 3$ ', H4" and H5" shifted upfield as well the phenylalanine protons H2 and H6. The acetyl NH was only disturbed after addition of 5 up to 15 equiv of $\mathrm{F}^{-}$shifting downfield and becoming broader (Figure 5). Although not shown in the figure, one triplet appeared at lower field $(\approx 16.5 \mathrm{ppm})$ suggesting the formation of $\mathrm{HF}_{2}^{-}$ion, thus providing additional confirmation of the deprotonation of the imidazole $\mathrm{NH}[5 \mathrm{~d}, \mathrm{e}, \mathrm{f}]$.

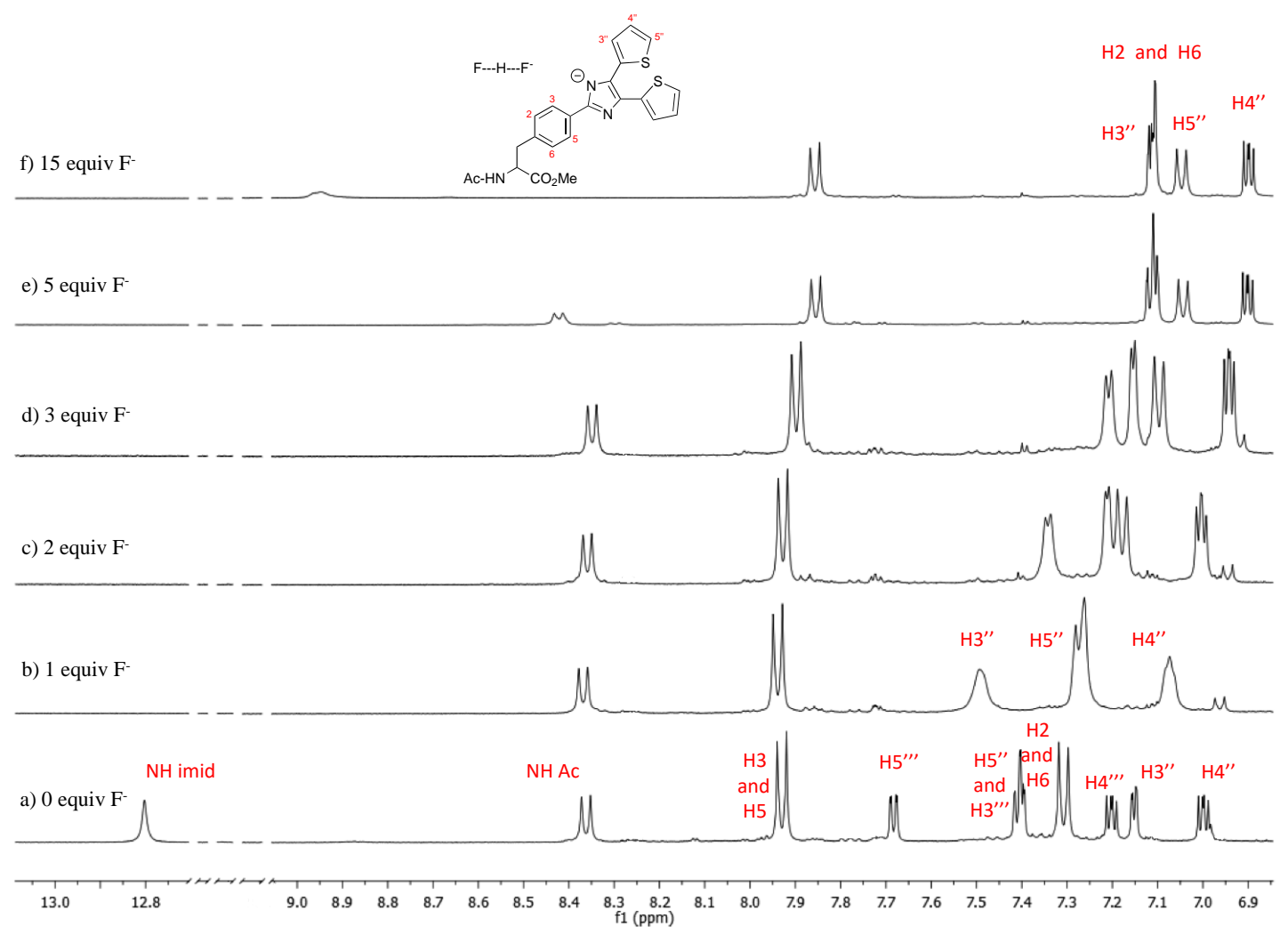

Figure 5. Partial ${ }^{1} \mathrm{H}$ NMR spectra of compound $3 \mathbf{b}\left(1.7 \times 10^{-2} \mathrm{M}\right)$ in DMSO- $d_{6}$ in the absence (a) and the presence of 1.0 (b), 2.0 (c), 3.0 (d), 5.0 (e) and 15.0 (f) equivalents of $\mathrm{F}^{-}$(in the form of its tetrabutylammonium salt). 
As for the titration with $\mathrm{Cu}^{2+}$, there was a considerable broadening of the proton signals, as expected, but similar tendencies were seen in the chemical shifts. Upon addition of only 0.5 equiv of $\mathrm{Cu}^{2+}$, the imidazole $\mathrm{NH}$ significantly broadened while the thiophene protons coalesced into only one set of proton signals. With increasing addition of the cation, these protons shifted upfield, but to a lesser extent when compared to the titration with $\mathrm{F}^{-}$(Figure $6)$.

Based on the results of the spectrofluorimetric and ${ }^{1} \mathrm{H}$ NMR titrations, a coordination scheme can be proposed involving the amino acid side chain: the observed chemical shifts are tentatively ascribed to preferential interaction between the anion/cation with one of the imidazole nitrogens and the heteroatom of the pendant heterocyclic moiety (Figures 5 and 6).

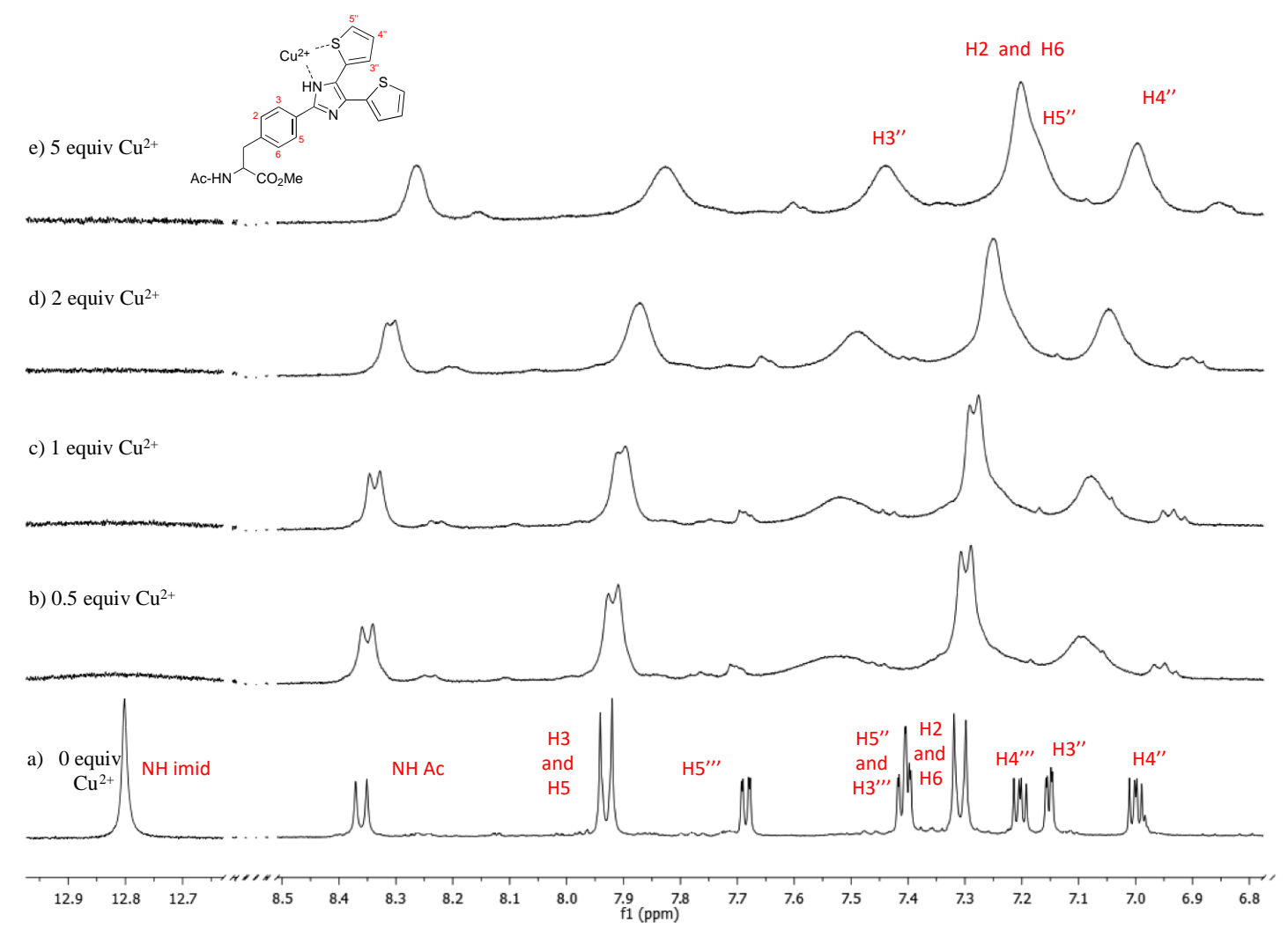

Figure 6. Partial ${ }^{1} \mathrm{H}$ NMR spectra of compound $3 \mathbf{b}\left(1.7 \times 10^{-2} \mathrm{M}\right)$ in DMSO- $d_{6}$ in the absence (a) and the presence of 0.5 (b), 1.0 (c), 2.0 (d), and 5.0 (e) equivalents of $\mathrm{Cu}^{2+}$ (in the form of its perchlorate salt).

The binding stoichiometry of 4,5-diarylimidazolyl-phenylalanines 3a-d with selected anions/cations and the binding affinity were calculated by HypSpec software from the 
spectrofluorimetric titrations in acetonitrile and aqueous acetonitrile, suggesting a 1:1 ligand:anion/metal cation stoichiometry (Table 4).

Table 4. Logarithmic association constants $\left(\log \mathrm{K}_{\mathrm{ass}}\right)$ for the interaction of 4,5diarylimidazolyl-phenylalanines 3a-d with several anions/cations in acetonitrile (L:M or L:A stoichiometry suggested from HypSpec is 1:1).

\begin{tabular}{|c|c|c|c|}
\hline Ligand & Ion & $\begin{array}{l}\log \mathrm{K}_{\mathrm{ass}} \\
(\mathrm{ACN})\end{array}$ & $\begin{array}{c}\log \mathrm{K}_{\mathrm{ass}} \\
\left(\mathrm{ACN} / \mathrm{H}_{2} \mathrm{O} 80: 20\right)\end{array}$ \\
\hline \multirow[t]{5}{*}{$3 \mathbf{a}$} & $\mathrm{Cu}^{2+}$ & $10.31 \pm 0.07$ & ----- \\
\hline & $\mathrm{Fe}^{3+}$ & $11.07 \pm 0.08$ & $8.38 \pm 0.01$ \\
\hline & $\mathrm{Hg}^{2+}$ & $10.23 \pm 0.02$ & $9.17 \pm 0.03$ \\
\hline & $\mathrm{Pd}^{2+}$ & $10.17 \pm 0.09$ & ----- \\
\hline & $\mathrm{F}^{-}$ & $9.24 \pm 0.11$ & ----- \\
\hline \multirow[t]{5}{*}{$\mathbf{3 b}$} & $\mathrm{Cu}^{2+}$ & $11.5 \pm 0.23$ & ----- \\
\hline & $\mathrm{Fe}^{3+}$ & $11.3 \pm 0.12$ & $7.42 \pm 0.09$ \\
\hline & $\mathrm{Hg}^{2+}$ & $10.9 \pm 0.34$ & ----- \\
\hline & $\mathrm{Pd}^{2+}$ & $11.8 \pm 0.41$ & ----- \\
\hline & $\mathrm{F}^{-}$ & $7.74 \pm 0.31$ & ----- \\
\hline \multirow[t]{5}{*}{$3 c$} & $\mathrm{Cu}^{2+}$ & $12.09 \pm 0.53$ & ----- \\
\hline & $\mathrm{Fe}^{3+}$ & $12.31 \pm 0.09$ & $8.25 \pm 0.12$ \\
\hline & $\mathrm{Hg}^{2+}$ & $10.27 \pm 0.05$ & ----- \\
\hline & $\mathrm{Pd}^{2+}$ & $10.44 \pm 0.15$ & ----- \\
\hline & $\mathrm{F}^{-}$ & $10.08 \pm 0.21$ & ----- \\
\hline \multirow[t]{5}{*}{$3 d$} & $\mathrm{Cu}^{2+}$ & $12.25 \pm 0.04$ & ----- \\
\hline & $\mathrm{Fe}^{3+}$ & $12.92 \pm 0.14$ & $9.12 \pm 0.02$ \\
\hline & $\mathrm{Hg}^{2+}$ & $11.88 \pm 0.03$ & ----- \\
\hline & $\mathrm{Pd}^{2+}$ & $11.48 \pm 0.07$ & ----- \\
\hline & $\mathrm{F}^{-}$ & $9.44 \pm 0.08$ & ----- \\
\hline
\end{tabular}

The 1:1 stoichiometry of the complex formed between probes $\mathbf{3 a - d}$ and $\mathrm{Cu}^{2+}$ was confirmed by spectrofluorimetry by the method of continuous variation and the Job's plot for the 
interaction between $\mathbf{3 a}$ and $\mathbf{3 b}$ (as representative examples) and the divalent cation is shown in Figure 7.
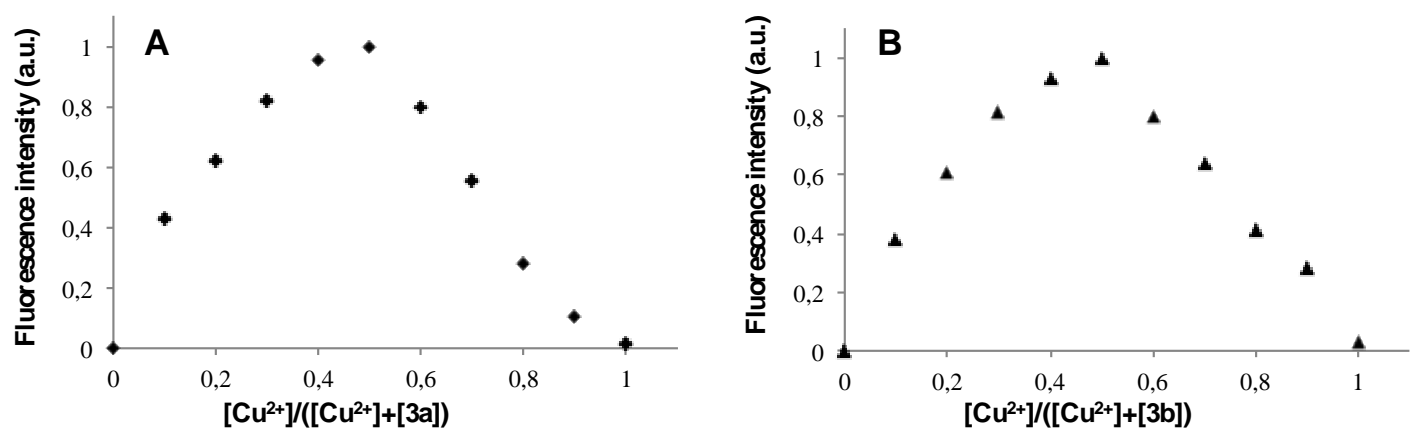

Figure 7. Job's plot for the interaction of $\mathbf{3 a}(\mathrm{A})$ and $\mathbf{3 b}(\mathrm{B})$ with $\mathrm{Cu}^{2+}$, in the form of perchlorate salt, as determined by spectrofluorimetry in acetonitrile at $413 \mathrm{~nm}$ for 3a $([\mathbf{3 a}]+$ $\left.\left[\mathrm{Cu}^{2+}\right]=1.0 \times 10^{-5} \mathrm{M}\right)$ and $422 \mathrm{~nm}$ for $\mathbf{3 b}\left([\mathbf{3 b}]+\left[\mathrm{Cu}^{2+}\right]=1.0 \times 10^{-5} \mathrm{M}\right)$.

In summary, the advantages of using such unnatural amino acids as sensory units, when compared to natural amino acids, for example, are as follows: the extra heteroatoms at the side chain can exert a cooperative effect for a more efficient binding process and the overall sensing ability; they show enhanced optical response as compounds 3a-c are much more fluorescent than tryptophan (the most fluorescent natural amino acid with a fluorescence quantum yield of 0.14). This allows higher detection sensitivity, thus lowering detection and quantification limits. Nevertheless, compound $\mathbf{3 d}$ has the same fluorescence quantum yield as tryptophan but it displays longer wavelengths of absorption (excitation) and fluorescence, which is useful for certain biological applications; their intrinsic biological nature and their potential for use in a variety of biological assays based on fluorescence spectroscopy.

\section{Conclusions}

The novel 4,5-diarylimidazolyl-phenylalanines 3a-d displayed modest to excellent fluorescence quantum yields $\left(\Phi_{\mathrm{F}}=0.64-0.77\right.$ for $\mathbf{3 a} ; \Phi_{\mathrm{F}}=0.14-0.30$ for $\mathbf{3 b} ; \Phi_{\mathrm{F}}=0.20-0.46$ and for 3c $\Phi_{\mathrm{F}}=0.02-0.14$ ) and large Stokes' shifts (between 86 and $119 \mathrm{~nm}$ or 6253 and $9099 \mathrm{~cm}^{-1}$ ) in organic solvents of different character. 4,5-Di(furan-2'-yl)imidazolylphenylalanine 3a displayed the highest relative fluorescence yield in all the solvents and aqueous mixtures. Through spectrofluorimetric titrations with several ions it was found that phenylalanines 3a-d showed high sensitivity and ability to interact with $\mathrm{Cu}^{2+}$ and $\mathrm{Fe}^{3+}$ in 
ACN but this sensitivity decreased in $\mathrm{ACN} / \mathrm{H}_{2} \mathrm{O}$ (80:20). The derivatives containing the fivemembered heterocycles $\mathbf{3 a}$ (furan) and $\mathbf{3 b}$ (thiophene) required less equivalents to show a complete fluorescence quenching, when compared to derivatives $\mathbf{3 c}-\mathbf{d}$, which can be related to the effect of the electron donor oxygen and sulphur atoms on the overall complexation ability. Due to their emissive character and their cation sensing properties, these heterocyclic amino acids could find application as useful building blocks for peptides with extra functionality due to their UV-active/fluorescent chromophore and complexing capability.

\section{Acknowledgments}

Thanks are due to Fundação para a Ciência e Tecnologia (FCT-Portugal) and FEDERCOMPETE for financial support through Centro de Química [PEst-C/QUI/UI0686/2011 (FCOMP-01-0124-FEDER-022716)] and a $\mathrm{PhD}$ grant to C.I.C. Esteves (SFRH/BD/68360/2010). The NMR spectrometer Bruker Avance III 400 is part of the National NMR Network and was purchased with funds from FCT and FEDER.

\section{References}

[1] You L, Zha D, Anslyn EV. Recent advances in supramolecular analytical chemistry using optical sensing. Chem Rev 2015;115:7840-7892.

[2] (a) Qian X, Xu Z. Fluorescence imaging of metal ions implicated in diseases. Chem Soc Rev 2015; 44:4487-4493.

(b) Yuan L, Lin W, Zheng K, Zhu S. FRET- based small-molecule fluorescent probes: rational design and bioimaging applications. Acc Chem Res 2013;46:1462-73.

(c) Kaur K, Saini R, Kumar A, Luxami V, Kaur N, Singh P, Kumar S. Chemodosimeters: an approach for estimation of biologically relevant metal ions and anions. Coord Chem Rev 2012;256:1992-2028.

(d) Wang S, Li N, Pan W, Tang B. Advances in functional fluorescent and luminescent probes for imaging intracellular small-molecule reactive species. Trends Anal Chem 2012;39:3-37.

(e) Que EL, Chang CJ. Responsive magnetic resonance imaging contrast agents as chemical sensors for metals in biology and medicine. Chem Soc Rev 2010;39:51-60.

[3] (a) Lozano-Torres B, El Sayed S, Costero AM, Gil S, Parra M, Martínez-Máñez R, Sancenón F. Selective and sensitive chromogenic detection of trivalent metal cations in water. Bull Chem Soc Japan 2016;89:498-500. 
(b) Ma Q, Li Y, Su X. Silica-nanobead-based sensors for analytical and bioanalytical applications. Trends Anal Chem 2015;74:130-145.

(c) Saura AV, Marín MJ, Burguete MI, Russell DA, Galindo F, Luis SV. The synthesis of new fluorescent bichromophoric compounds as ratiometric $\mathrm{pH}$ probes for intracellular measurements. Org Biomol Chem 2015;13:7736-7749.

(d) Santos-Figueroa LE, Moragues ME, Climent E, Agostini A, Martínez-Máñez R, Sancenón F. Chromogenic and fluorogenic chemosensors and reagents for anions. A comprehensive review of the years 2010-2011. Chem Soc Rev 2013;42:3489-613.

(e) Formica M, Fusi V, Giorgi L, Micheloni M. New fluorescent chemosensors for metal ions in solution. Coord Chem Rev 2012;256:170-92.

(f) Doussineau T, Schulz A, Lapresta-Fernandez A, Moro A, Korsten S, Trupp S, Mohr GJ. On the design of fluorescent ratiometric nanosensors. Chem Eur J 2010;16:10290-10299.

[4] (a) Molina P, Tarraga A, Oton F. Imidazole derivatives: a comprehensive survey of their recognition properties. Org Biomol Chem 2012;10:1711-1724.

(b) $\mathrm{Xu} \mathrm{Z}$, Kim S, Yoon J. Revisit to imidazolium receptors for the recognition of anions: highlighted research during 2006-2009. Chem Soc Rev 2010;39:1457-1466.

(c) Alfonso M, Ferao AE, Tarraga A, Molina P. Electrochemical and fluorescent ferrocene-imidazole-based dyads as ion-pair receptors for divalent metal cations and oxoanions. Inorg Chem 2015;54:7461-7473.

[5] (a) Marín-Hernández C, Santos-Figueroa LE, El Sayed S, Pardo T, Raposo MMM, Batista RMF, Costa SPG, Sancenón F, Martínez-Máñez R. Synthesis and evaluation of the chromo-fluorogenic recognition ability of imidazoquinoline derivatives toward ions. Dyes Pigments 2015;122:50-58.

(b) Marín-Hernández C, Santos-Figueroa LE, Moragues ME, Raposo MMM, Batista RMF, Costa SPG, Pardo T, Martínez-Máñez R, Sancenón F. Imidazoanthraquinone derivatives for chromofluorogenic sensing of basic anions and trivalent metal cations. $\mathbf{J}$ Org Chem 2014;79:10752-10761.

(c) Batista RMF, Costa SPG, Raposo MMM. Selective colorimetric and fluorimetric detection of cyanide in aqueous solution using novel heterocyclicimidazo-anthraquinones. Sensors Act B Chem 2014;191:791-799.

(d) Batista RMF, Oliveira E; Costa SPG, Lodeiro C, Raposo MMM. Cyanide and fluoride colorimetric sensing by novel imidazo-anthraquinones functionalized with indole and carbazole. Supramol Chem 2014;26:71-80. 
(e) Batista RMF, Costa SPG, Raposo MMM. Naphtyl-imidazo-anthraquinones as novel colorimetric and fluorimetric chemosensors for ion sensing. J Photochem Photobiol A 2013;259:33-40.

(f) Batista RMF, Oliveira E, Costa SPG, Lodeiro C, Raposo MMM. Synthesis and ion sensing properties of new colorimetric and fluorimetric chemosensors based on bithienylimidazo-anthraquinone chromophores. Org Lett 2007;9:3201-3204.

[6] (a) Pina J, Seixas de Melo J, Batista RMF, Costa SPG, Raposo MMM. Synthesis and characterization of the ground and excited states of tripodal-like oligothienyl imidazoles. J. Phys. Chem B 2010;114:4964-4972.

(b) Oliveira E, Batista RMF, Costa SPG, Lodeiro C, Raposo MMM. Exploring the emissive properties of new azacrown compounds bearing aryl, furyl, or thienyl moieties: a special case of chelation enhancement of fluorescence upon interaction with $\mathrm{Ca}^{2+}, \mathrm{Cu}^{2+}$ or $\mathrm{Ni}^{2+}$. Inorg Chem 2010;49:10847-10857.

(c) Pawlicki M, Collins HA, Denning RG, Anderson HL. Two-photon absorption and the design of two-photon dyes. Angew Chem Int Ed 2009;48:3244-3266.

(d) Batista RMF, Costa SPG, Belsley M, Lodeiro C, Raposo MMM. Synthesis and characterization of novel (oligo)thienyl-imidazo-phenanthrolines as versatile $\pi$-conjugated systems for several optical applications. Tetrahedron 2008;64:9230-9238.

(e) Batista RMF, Costa SPG, Belsley M, Raposo MMM. Synthesis and evaluation of the optical properties of novel thermally stable phenanthrolines bearing a arylthienyl-imidazo conjugation pathway. Dyes Pigments 2009;80:329-336.

[7] (a) Rani N, Sharma A, Gupta GK, Singh R. Imidazoles as potential antifungal agents: a review. Mini-rev Med Chem 2013;13:1626-1655.

(b) Pedras B, Batista RMF, Tormo L, Costa SPG, Raposo MMM, Orellana G, Capelo JL, Lodeiro C. Synthesis, characterization, photophysical studies and interaction with DNA of a new family $\mathrm{Ru}(\mathrm{II})$ furyl- and thienyl-imidazo-phenanthroline polypyridyl complexes. Inorg Chim Acta 2012;381:95-103.

(c) Narasimhan B, Sharma D, Kumar P. Biological importance of imidazole nucleus in the new millennium. Med Chem Res 2011;20:1119-1140.

(d) Li J, Zheng W, Shi S, Tan V, Chen J, Zheng K, Ji L. Synthesis, antitumor activity and structure-activity relationships of a series of $\mathrm{Ru}(\mathrm{II})$ complexes. J Inorg Biochem 2008;102:193-202. 
[8] (a) Zhou L, Shao J, Li Q, van Heel AJ, de Vries MP, Broos J, Kuipers OP. Incorporation of tryptophan analogues into the lantibiotic nisin. Amino Acids 2016;48:1309-1318.

(b) Liu Q, Wang J, Boyd BJ. Peptide-based biosensors. Talanta 2015;136:114-127.

(c) Pless SA, Ahern CA. Unnatural amino acids as probes of ligand-receptor interactions and their conformational consequences. Annu Rev Pharmacol Toxicol 2013;53:211-29.

(d) Niu W, Guo J. Expanding the chemistry of fluorescent protein biosensors through genetic incorporation of unnatural amino acids. Mol BioSyst 2013;9:2961-2970.

(e) Wang A, Nairn NW, Marelli M, Grabstein K. Protein engineering with non-natural amino acids. In: Kaumaya P. (ed) Protein Engineering, In Tech, Rijeka, 2012, pp 253-290.

(f) Lee S, Xie J, Chen X. Peptide-based probes for targeted molecular imaging. Biochemistry 2010;49:1364-1376.

(g) Katritzki A R, Narindoshvili T. Fluorescent amino acids: advances in protein-extrinsic fluorophores. Org. Biomol. Chem. 2009;7:627-624.

(h) Kajihara D, Abe R, Iijima I, Komiyama C, Sissido M, Hohsaka T. FRET analysis of protein conformational change through position-specific incorporation of fluorescent amino acids. Nature Methods 2006;3:923-929.

(i) Ishida H, Kyakuno M, Oishi S. Molecular design of functional peptides by utilizing unnatural amino acids: toward artificial and photofunctional protein. Biopolymers (Pep. Sci.) 2004;76:69-82.

(j) Hodgson DRW, Sanderson JM. The synthesis of peptides and proteins containing nonnatural amino acids. Chem. Soc. Rev. 2004, 33, 422-430.

[9] (a) Oliveira E, Genovese D, Juris R, Zaccheroni N, Capelo JL, Raposo MMM, Costa SPG, Prodi L, Lodeiro C. Bioinspired systems for metal-ion sensing: new emissive peptide probes based on benzo[d]oxazole derivatives and their gold and silica nanoparticles. Inorg Chem 2011;50: 8834-8849.

(b) Shimazaki Y, Takani M, Yamauchi O. Metal complexes of amino acids and amino acid side chain groups. Structures and properties. Dalton Trans 2009;38:7854-7869.

(c) Zheng Y, Cao X, Orbulescu J, Konka V, Andreopoulos FM, Pham SM, Leblanc R M. Peptidyl fluorescent chemosensors for the detection of divalent copper. Anal Chem 2003;75:1706-1712.

[10] (a) Costa SPG, Oliveira E, Lodeiro C, Raposo MMM. Heteroaromatic alanine derivatives bearing (oligo)thiophene units: synthesis and photophysical properties. Tetrahedron Lett 2008;49:5258-5261. 
(b) Costa SPG, Batista RMF, Raposo MMM. Synthesis and photophysical characterization of new fluorescent bis-amino acids bearing a heterocyclic bridge containing benzoxazole and thiophene. Tetrahedron 2008;64:9733-9737.

(c) Esteves CIC, Silva AMF, Raposo MMM, Costa SPG. Unnatural benz-X-azolyl asparagine derivatives as novel fluorescent amino acids: synthesis and photophysical characterization. Tetrahedron 2009;65:9373-9377.

[11] (a) Batista RMF, Isakov D, Raposo MMM, Belsley M, Bdikin I, Kholkin AL, Costa SPG, de Matos Gomes E. Ferroelectric nanofibers with an embedded optically nonlinear benzothiazole derivative. J Nanopart Res 2014;16:2502.

(b) Pina J, Seixas de Melo J, Batista RMF, Costa SPG, Raposo MMM. Triphenylaminebenzimidazole derivatives: synthesis, excited-state characterization and DFT studies. J Org Chem 2013;78:11389-11395.

(c) Batista RMF, Oliveira E, Costa SPG, Lodeiro C, Raposo MMM. (Oligo)thienylimidazo-crown ether derivatives: synthesis, photophysical studies and evaluation of their chemosensory properties. Talanta 2011;85: 2470-2478.

(d) Batista RMF, Oliveira E, Costa SPG, Lodeiro C, Raposo MMM. Imidazo-benzo-15crown-5 ether bearing arylthienyl and bithienyl moieties as novel fluorescent chemosensors for $\mathrm{Pd}^{2+}$ and $\mathrm{Cu}^{2+}$. Tetrahedron 2011;67:7106-7113.

(e) Pina J, Seixas de Melo J, Batista RMF, Costa SPG, Raposo MMM. The influence of the relative position of the thiophene and pyrrole rings in donor-acceptor thienylpyrrolyl benzothiazole derivatives. A photophysical and theoretical investigation. Phys Chem Chem Phys 2010;12:9719-9725.

(f) Batista RMF, Costa SPG, Malheiro EL, Belsey M, Raposo MMM. Synthesis and characterization of new thienylpyrrolyl-benzothiazoles as efficient and thermally stable nonlinear optical chromophores. Tetrahedron 2007;63:4258-4265.

(g) Batista RMF, Costa SPG, Belsey M, Raposo MMM. Synthesis and second-order nonlinear optical properties of new chromophores containing benzimidazole, thiophene and pyrrole heterocycles. Tetrahedron 2007;63:9842-9849.

(h) Pina J, Seixas de Melo J, Burrows HD, Batista RMF, Costa SPG, Raposo MMM. Spectral and photophysical characterization of donor- $\pi$-acceptor arylthienyl- and bithienyl-benzothiazole derivatives in solution and solid state. J Phys Chem A 2007;111:8574-8578. 
(i) Costa SPG, Batista RMF, Cardoso P, Belsey M, Raposo MMM. 2-Arylthienylsubstituted 1,3-benzothiazoles as new nonlinear optical chromophores. Eur J Org Chem $2006 ; 17: 3938-3946$.

(h) Batista RMF, Costa SPG, Raposo MMM. Synthesis of new fluorescent 2-(2,2'bithienyl)-1,3-benzothiazoles. Tetrahedron Lett 2004;45:2825-2828.

[12] (a) Esteves CIC, Batista RMF, Costa SPG, Raposo MMM. Novel functionalised imidazo-benzocrown ethers bearing a thiophene spacer as fluorimetric chemosensors for metal ion detection. Dyes Pigments 2016, doi:10.1016/j.dyepig.2016.04.037.

(b) Batista RMF, Ferreira RCM, Raposo MMM, Costa SPG. Novel optical chemosensors for anions and cations based on an amino acid core functionalised with benzimidazoles. Tetrahedron 2012;68:7322-7330.

(c) Oliveira E, Costa SPG, Raposo MMM, Faza ON, Lodeiro C. Synthesis, characterization, fluorescence and computational studies of new $\mathrm{Cu}^{2+}, \mathrm{Ni}^{2+}$ and $\mathrm{Hg}^{2+}$ complexes with emissive thienylbenzoxazolyl-alanine ligands. Inorg Chim Acta 2011;366:154-160.

(d) Esteves CIC, Raposo MMM, Costa SPG. Novel highly emissive non proteinogenic amino acids: synthesis of 1,3,4-thiadiazolyl asparagines and evaluation as fluorimetric chemosensors for biologically relevant transition metal cations. Amino Acids 2011;40:1065-1075.

(e) Esteves CIC, Raposo MMM, Costa SPG. Synthesis and evaluation of benzothiazolyl and benzimidazolyl asparagines as amino acid based selective fluorimetric chemosensors for $\mathrm{Cu}^{2+}$. Tetrahedron 2010;66:7479-7486.

(f) Costa SPG, Oliveira E, Lodeiro C, Raposo MMM. Synthesis, characterization and metal ion detection of novel fluoroionophores based on heterocyclic substituted alanines. Sensors 2007;7:2096-2114.

[13] (a) Morera E, Ortar G, Varani A. An improved preparation of 4-hydroxymethyl-Lphenylalanine. Synth Commun 1998;28:4279-4285.

(b) Shieh W-C, Carlson JA. A simple asymmetric-synthesis of 4-arylphenylalanines via palladium-catalyzed cross-coupling reaction of arylboronic acids with tyrosine triflate. $\mathbf{J}$ Org Chem 1992;57:379-381.

[14] Morris JV, Mahaney MA, Huber JR. Fluorescence quantum yield determinations - 9,10diphenylanthracene as a reference-standard in different solvents. J Phys Chem 1976;80:969-974. 
[15] Hernandez Munoz JA, Junior JJ, Martins da Silva F. Radziszewski reaction: an elegant, easy, simple and efficient method to synthesise imidazoles. Curr Org Synth 2014;11:824834.

[16] (a) Kamlet MJ, Abboud JL, Taft RW. The solvatochromic comparison method. 6. The pi* scale of solvent polarities. J Am Chem Soc 1977; 99:6027-38.

(b) Kamlet MJ, Abboud JLM, Abraham MH, Taft RW. Linear solvation energy relationships 23. A comprehensive collection of the solvatochromic parameters, pi*, alpha, and beta, and some methods for simplifying the generalized solvatochromic equation. $\mathbf{J}$ Org Chem 1983;48:2877. 